\section{A look at Mayan artificial cranial deformation practices: morphological and cultural aspects}

TO THE EDITOR AND READERSHIP: On behalf of all authors, I respectfully request retraction of our article, "A look at Mayan artificial cranial deformation practices: morphological and cultural aspects" (Neurosurg Focus 29(6):E2, 2010) in response to complaints from Vera Tiesler, $\mathrm{PhD}$, Professor of Anthropological Sciences at the Autonomous University of Yucatán, and Lic. Maria del Perpetuo Socorro Villarreal Escárrega, National Coordinator for Legal Affairs at the National Institute of Anthropology and History (INAH).

Dr. Tiesler accused us of "mishandling and violations of the paternity of [her] intellectual property." We apologize for any misrepresentation of her work that we may have made, specifically with respect to the following papers, which we referenced in our paper:

17. Tiesler V: La costumbre de la deformación cefálica entre los antiguos mayas; aspectos morfológicos y culturales. Mexico: Instituto Nacional de Antropología e Historia, 1998, $\mathrm{p} 42$

18. Tiesler V: La deformación cefálica intencional entre los mayas prehispánicos; aspectos morfológicos y culturales. Tesis de Maestría en Arqueología. Mexico: Escuela Nacional de Antropología e Historia, 1994
It was not our intention to mislead readers about Dr. Tiesler's accomplishments. We believe that Dr. Tiesler was properly cited in our paper. However, we were unable to come to an agreement with her on this issue that would benefit all parties including the scientific community.

An additional complaint against our paper was that we did not obtain the appropriate permission to reproduce the figures, which we attributed to Dr. Tiesler but which actually belong to the INAH. We admit that we did not follow proper channels to obtain permission.

We have received requests that we remove our discussion of Dr. Tiesler's works and the figures belonging to INAH. We realize that these materials are integral parts of our paper, and their removal would leave a very large gap in the paper.

We as authors are willing to cooperate with INAH and the Journal of Neurosurgery Publishing Group. The best way to set the record straight in this matter is to formally retract the paper from the literature. We apologize to the editors and readers of Neurosurgical Focus. We appreciate the opportunity to retract this paper.

Arturo Sotomayor-González, MD

National Institute of Neurology and Neurosurgery, Tlalpan, Mexico

INCLUDE WHEN CITING

DOI: 10.3171/2018.5.FOCUS10200r.

CAANS 2018, except where prohibited by US copyright law 